\title{
ANALISIS SISTEM ANTRIAN PADA LOKET PEMBAYARAN PT. PLN (PERSERO) AREA BALI SELATAN RAYON KUTA
}

\author{
GDE NGURAH PRABA MARTHA ${ }^{1}$, I KOMANG GDE SUKARSA ${ }^{2}$, I PUTU EKA NILA \\ KENCANA $^{3}$ \\ ${ }^{1,2,3}$ Jurusan Matematika FMIPA Universtitas Udayana, Bukit Jimbaran 80361, \\ email: prabagas.matik@gmail.com
}

\begin{abstract}
The purpose of the analysis of queuing systems is to find out the model and the performance of queuing system was run. The research was conducted at PT. PLN (Persero) South Bali Area Rayon Kuta and the issue raised is about the analysis of queuing systems at the payment counter. Model queue is determined based on the Kendall notation and performance of queuing systems can be determined by calculating the utilization factor. At payment counter, the queuing model used is a

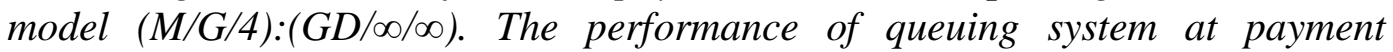
counter of PT. PLN (Persero) South Bali Area Rayon Kuta is less effective because each servers was busy on average only between $30 \%-50 \%$ of working hours so that more time unemployed servers.
\end{abstract}

Keywords: Queuing System, Payment Counter, Queuing Model

\section{Pendahuluan}

Mengantri merupakan salah satu fenomena yang sering terjadi dalam kehidupan sehari-hari dan sering ditemui dalam fasilitas-fasilitas pelayanan umum. Mengantri akan terjadi bila banyaknya pelanggan yang dilayani melebihi kapasitas layanan yang tersedia. Untuk mengurangi masalah yang terjadi pada suatu antrian, maka pada fasilitas pelayanan perlu dilakukan analisis sistem antrian.

Sistem antrian merupakan suatu proses kelahiran-kematian suatu populasi yang terdiri atas para pelanggan yang sedang menunggu mendapatkan pelayanan atau yang sedang dilayani [1]. Unsur-unsur penting yang terkait dengan sistem antrian yaitu distribusi kedatangan, distribusi waktu pelayanan, fasilitas pelayanan, disiplin pelayanan, ukuran antrian, dan sumber pemanggilan [2].

Tujuan dari analisis sistem antrian yaitu untuk mengetahui model dan kinerja sistem antrian yang sudah dijalankan. Selain itu, sistem antrian juga digunakan untuk mengidentifikasi permasalahan yang terjadi dan sebagai pedoman dalam menentukan kebijakan bagi perusahaan.

PT. PLN (Persero) Area Bali Selatan Rayon Kuta merupakan salah satu unit sarana pelayanan listrik yang dimiliki oleh PT. PLN (Persero) Area Bali Selatan. 
Pada loket pembayaran, pelayanan yang dilalukan meliputi pelayanan pembayaran pasang baru, tambah daya, dan migrasi dari listrik pasca bayar menuju ke prabayar. Dalam memberikan pelayanan kepada pelanggan, PT. PLN (Persero) Area Bali Selatan Rayon Kuta harus benar-benar optimal dalam memilih dan menerapkan sebuah konsep dalam mengatur sistem operasionalnya, khususnya dalam penerapan sistem antrian pada bagian loket pembayaran.

Berdasarkan latar belakang yang telah diuraikan, maka penelitian ini bertujuan untuk mengetahui model antrian dan kinerja sistem antrian pada loket pembayaran PT. PLN (Persero) Area Bali Selatan Rayon Kuta.

\section{Metode Penelitian}

Penelitian ini dilakukan di PT. PLN (Persero) Area Bali Selatan Rayon Kuta, beralamat di Jalan Sunset Road, Badung, pada bulan Desember 2011. Jenis data yang digunakan dalam penelitian ini berupa data kuantitatif yaitu data yang berbentuk angka-angka dan dapat dihitung dengan satuan hitung. Sumber data yang digunakan dalam penelitian ini adalah data primer, yaitu data kedatangan pelanggan PT. PLN (Persero) Area Bali Selatan Rayon Kuta tanggal 19-23 Desember 2011. adalah:

Metode pengumpulan data yang digunakan dalam penyusunan laporan ini

1. Metode Observasi

Penulis melakukan pengamatan langsung di PT. PLN (Persero) Area Bali Selatan Rayon Kuta. Dalam hal ini, permasalahan yang diangkat adalah mengenai analisis sistem antrian pada bagian loket pembayaran.

2. Metode Wawancara

Penulis melakukan tanya jawab dengan pimpinan dan pegawai PT. PLN (Persero) Area Bali Selatan Rayon Kuta tentang materi-materi yang berkaitan dengan masalah yang akan diangkat maupun hal-hal yang menunjang aktivitas perusahaan.

3. Metode Literatur

Penulis membaca buku-buku pedoman yang terdapat di perusahaan atau yang berhubungan dengan penyusunan laporan ini.

Untuk mencapai tujuan penelitian ini, maka langkah-langkah analisis yang dilakukan adalah sebagai berikut:

1. Menginput data, yaitu data kedatangan pelanggan dan waktu pelayanan.

2. Melakukan uji kecocokan distribusi terhadap pola kedatangan dan pola pelayanan dengan Kolmogorov-Smirnov [3].

Hipotesis tentang distribusi kedatangan adalah sebagai berikut:

$\mathrm{H}_{0}$ : Kedatangan pelanggan PT. PLN (Persero) Area Bali Selatan Rayon Kuta berdistribusi Poisson.

$\mathrm{H}_{1}$ : Kedatangan pelanggan PT. PLN (Persero) Area Bali Selatan Rayon Kuta tidak berdistribusi Poisson.

Jika tidak berdistribusi Poisson, maka kedatangan diasumsikan berdistribusi umum (general). 
Hipotesis tentang waktu pelayanan adalah sebagai berikut:

$\mathrm{H}_{0}$ : Waktu pelayanan pelanggan PT. PLN (Persero) Area Bali Selatan Rayon Kuta berdistribusi Eksponensial.

$\mathrm{H}_{1}$ : Waktu pelayanan pelanggan PT. PLN (Persero) Area Bali Selatan Rayon Kuta tidak berdistribusi Eksponensial.

Jika tidak berdistribusi Eksponensial, maka waktu pelayanan diasumsikan berdistribusi umum (general) [4].

3. Menentukan model antrian berdasarkan notasi Kendall [5].

4. Menghitung ukuran kinerja sistem antrian, seperti $L_{s}, L_{q}, W_{s}$ dan $W_{q}$ dimana:

$L_{s}=$ jumlah pelanggan yang diperkirakan dalam sistem.

$L_{q}=$ jumlah pelanggan yang diperkirakan dalam antrian.

$W_{s}=$ waktu tunggu yang diperkirakan dalam sistem.

$W_{q}=$ waktu tunggu yang diperkirakan dalam antrian[6].

5. Menghitung faktor utilisasi dengan melakukan pemeriksaan steady state.

\section{Hasil dan Pembahasan}

\section{Gambaran Perusahaan}

Fasilitas yang menunjang sistem pelayanan di PT. PLN (Persero) Area Bali Selatan Rayon Kuta meliputi bangku tunggu pelanggan, customer service, tempat pengambilan nomor antrian, tempat pengisian formulir, ruang VIP pelanggan, dan loket PLN. Khusus loket PLN, sebenarnya tersedia enam loket pembayaran, namun yang berfungsi hanya empat loket.

\section{Mengidentifikasi Model Antrian}

1. Uji Kecocokan Distribusi Kedatangan Pelanggan

Data kedatangan pelanggan akan diuji dengan uji kecocokan distribusi Kolmogorov-Smirnov dengan taraf nyata 5\% $(\alpha=0,05)$.

Tabel 1. Tabel Uji Kecocokan Distribusi Poisson Terhadap Kedatangan Pelanggan

\begin{tabular}{|c|c|c|c|}
\hline Hari, Tanggal & $\mathbf{N}$ & $\boldsymbol{D}=$ maksimum $\left|\boldsymbol{F}_{\boldsymbol{0}}(\boldsymbol{X})-\boldsymbol{S}_{\boldsymbol{N}}(\boldsymbol{X})\right|$ & $\boldsymbol{P}$-Value \\
\hline Senin, 19 Desember 2011 & 8 & 0,315 & 0,404 \\
\hline Selasa, 20 Desember 2011 & 8 & 0,273 & 0,591 \\
\hline Rabu, 21 Desember 2011 & 8 & 0,298 & 0,475 \\
\hline Kamis, 22 Desember 2011 & 8 & 0,185 & 0,947 \\
\hline Jumat, 23 Desember 2011 & 8 & 0,188 & 0,940 \\
\hline
\end{tabular}

Berdasarkan Tabel 1, terlihat bahwa nilai $P$-Value $>\alpha$, sehingga tidak cukup bukti untuk menolak $\mathrm{H}_{0}$. Jadi, dapat disimpulkan bahwa kedatangan pelanggan berdistribusi Poisson. 
2. Uji Kecocokan Distribusi Lama Waktu Pelayanan

Data waktu pelayanan akan diuji dengan uji kecocokan distribusi Kolmogorov-Smirnov dengan taraf nyata 5\% $(\alpha=0,05)$.

Tabel 2. Tabel Uji Kecocokan Distribusi Eksponensial Terhadap Lama Waktu Pelayanan

\begin{tabular}{|c|c|c|c|}
\hline Hari, Tanggal & $\mathbf{N}$ & $\boldsymbol{D}=$ maksimum $\left|\boldsymbol{F}_{\boldsymbol{0}}(\boldsymbol{X})-\boldsymbol{S}_{\boldsymbol{N}}(\boldsymbol{X})\right|$ & $\boldsymbol{P}$-Value \\
\hline Senin, 19 Desember 2011 & 55 & 0,399 & 0,000 \\
\hline Selasa, 20 Desember 2011 & 50 & 0,406 & 0,000 \\
\hline Rabu, 21 Desember 2011 & 44 & 0,370 & 0,000 \\
\hline Kamis, 22 Desember 2011 & 66 & 0,407 & 0,000 \\
\hline Jumat, 23 Desember 2011 & 48 & 0,404 & 0,000 \\
\hline
\end{tabular}

Berdasarkan Tabel 2, terlihat bahwa nilai $P$-Value $<\alpha$, sehingga $\mathrm{H}_{0}$ ditolak. Jadi, dapat disimpulkan bahwa lama waktu pelayanan tidak berdistribusi eksponensial. Jika tidak berdistribusi eksponensial, maka lama waktu pelayanan diasumsikan berdistribusi umum (general).

\section{Desain dan Disiplin Antrian}

Dari hasil penelitian yang dilakukan, desain antrian yang dianut di PT. PLN (Persero) Area Bali Selatan Rayon Kuta mengikuti desain antrian dengan singlephase system (jalur berganda, satu tahap), yaitu umumnya terdapat empat pelayan untuk melayani pelanggan dan hanya melalui satu tahap pelayanan.

Sedangkan disiplin antrian yang dianut PT. PLN (Persero) Area Bali Selatan Rayon Kuta yaitu First Come First Serve (FCFS), dimana pelanggan yang mengambil nomor antrian pertama akan dilayani terlebih dahulu.

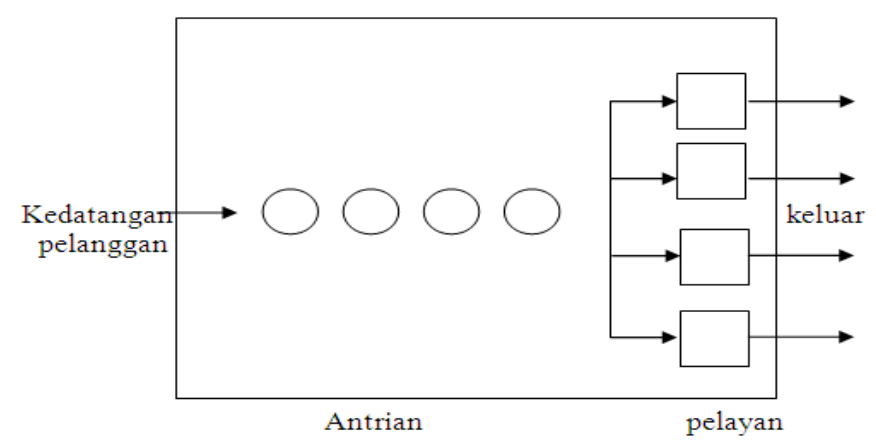

Gambar 1. Desain dan Disiplin Antrian di PT. PLN (Persero) Area Bali Selatan Rayon Kuta

\section{Kesimpulan Model Antrian}

Dari hasil penelitian, ternyata pola kedatangan pelanggan berdistribusi Poisson dan waktu pelayanan berdistribusi umum. Jumlah pelayan yang tersedia umumnya ada empat orang dengan peraturan pelayanan yang pertama kali mengambil nomor antrian akan dilayani terlebih dahulu. Jumlah pelanggan dalam 
sistem antrian serta sumber kedatangan pelanggan tak terbatas. Dengan demikian, dapat disimpulkan model antrian di PT. PLN (Persero) Area Bali Selatan Rayon

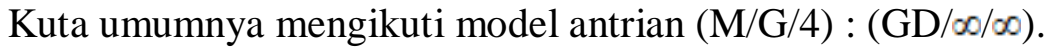

\section{Menghitung Kinerja Sistem Antrian}

Kinerja sistem meliputi $L_{s}, L_{q}, W_{s}$ dan $W_{q}$. Berikut diperoleh ukuran kinerja sistem antrian yang dirangkum pada tabel 4.3.

Tabel 3. Tabel Ukuran Kinerja Sistem Antrian PT. PLN (Persero) Area Bali Selatan Rayon Kuta

\begin{tabular}{|c|c|c|c|c|c|}
\hline Hari, Tanggal & Pelayan & $L_{s}$ & $L_{q}$ & $W_{s}$ & $W_{q}$ \\
\hline Senin, 19 Desember 2011 & 4 & 4,568 & 0,568 & 19,761 & 4,941 \\
\hline Selasa, 20 Desember 2011 & 3 & 3,408 & 0,408 & 17,362 & 3,922 \\
\hline Rabu, 21 Desember 2011 & 4 & 4,217 & 0,217 & 17,521 & 2,361 \\
\hline Kamis, 22 Desember 2011 & 4 & 4,867 & 0,867 & 19,693 & 6,283 \\
\hline Jumat, 23 Desember 2011 & 4 & 4,180 & 0,180 & 15,322 & 1,802 \\
\hline
\end{tabular}

Berdasarkan Tabel 3, diperoleh jumlah pelanggan yang diperkirakan dalam sistem $\left(L_{s}\right)$ antara 3-5 orang, jumlah pelanggan yang diperkirakan dalam antrian $\left(L_{q}\right)$ antara $0-1$ orang, waktu tunggu yang diperkirakan dalam sistem $\left(W_{s}\right)$ antara 15-20 menit, dan waktu tunggu yang diperkirakan dalam antrian $\left(W_{q}\right)$ antara 1-6 menit.

Untuk mengetahui faktor utilisasi, dilakukan pengukuran steady state. Dari hasil penelitian, diperoleh faktor utilisasi yang dirangkum dalam Tabel 4.

Tabel 4. Tabel Kinerja Sistem Antrian di PT. PLN (Persero) Area Bali Selatan Rayon Kuta

\begin{tabular}{|c|c|c|c|c|}
\hline Hari, Tanggal & $\begin{array}{c}\text { Laju Kedatangan } \\
\text { Pelanggan Tiap Menit } \\
(\lambda)\end{array}$ & $\begin{array}{c}\text { Laju Pelayanan } \\
\text { Tiap Menit }(\mu)\end{array}$ & $\begin{array}{c}\text { Banyak Pelayan } \\
\text { Sibuk }(c)\end{array}$ & $\begin{array}{c}\text { Faktor Utilisasi } \\
\left(\boldsymbol{\rho}=\frac{\boldsymbol{\lambda}}{\boldsymbol{c \mu}}\right)\end{array}$ \\
\hline Senin, 19 Desember 2011 & 0,115 & 0,067 & 4 & 0,429 \\
\hline Selasa, 20 Desember 2011 & 0,104 & 0,074 & 3 & 0,468 \\
\hline Rabu, 21 Desember 2011 & 0,092 & 0,066 & 4 & 0,348 \\
\hline Kamis, 22 Desember 2011 & 0,138 & 0,074 & 4 & 0,466 \\
\hline Jumat, 23 Desember 2011 & 0,100 & 0,074 & 4 & 0,338 \\
\hline
\end{tabular}

Berdasarkan Tabel 4, diperoleh nilai faktor utilisasi $(\rho=\lambda / c \mu)<1$ sehingga memenuhi kondisi steady state. Nilai faktor utilisasi yang diperoleh berkisar antara 0,3-0,5. Artinya dalam satu hari kerja, masing-masing pelayan rata-rata hanya sibuk antara 30\%-50\% dari jam kerja sehingga waktu menganggur pelayan tiap harinya lebih banyak. Dapat disimpulkan bahwa kinerja sistem antrian di PT. PLN (Persero) Area Bali Selatan Rayon Kuta kurang efektif. 


\section{Kesimpulan}

Berdasarkan uraian dari hasil penelitian, maka dapat diperoleh kesimpulan sebagai berikut:

1. Berdasarkan notasi Kendall, model antrian PT. PLN (Persero) Area Bali

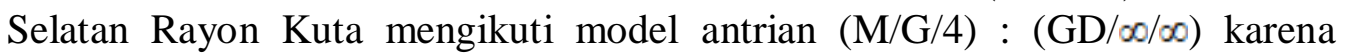
kedatangan pelanggan berdistribusi Poisson, waktu pelayanan berdistribusi umum (general), jumlah pelayan umumnya empat dengan peraturan pelayanan yang pertama kali mengambil nomor antrian akan dilayani terlebih dahulu, jumlah pelanggan yang diijinkan dalam sistem antrian dan sumber kedatangan pelanggan tak terbatas.

2. Jumlah pelanggan PT. PLN (Persero) Area Bali Selatan Rayon Kuta dalam sistem tiap harinya berkisar antara 3-5 orang, sedangkan jumlah pelanggan dalam antrian berkisar antara $0-1$ orang. Waktu tunggu pelanggan dalam sistem tiap harinya berkisar antara 15-20 menit, sedangkan waktu antri pelanggan berkisar antara 1-6 menit. Berdasarkan faktor utiisasi, kinerja sistem antrian PT. PLN (Persero) Area Bali Selatan Rayon Kuta kurang efektif karena masing-masing pelayan rata-rata hanya sibuk antara $30 \%-50 \%$ dari jam kerja sehingga waktu menganggur pelayan lebih banyak.

\section{Daftar Pustaka}

[1] Wospakrik, H.J. 1996. Teori dan Soal-soal Operations Research. Bandung: Erlangga.

[2] Kakiay, TJ. 2004. Dasar Teori Antrian Untuk Kehidupan Nyata. Yogyakarta: Andi.

[3] Sheskin, D.J. 2000. Handbook of Parametric and Nonparametric Statistical Procedures. Second Edition. Florida: Chapman and Hall/CRC.

[4] Sugito dan M Fauzia. 2009. "Analisis Sistem Antrian Kereta Api di Stasiun Besar Cirebon dan Stasiun Cirebon Prujakan”. Media Statistika (2), 111-120.

[5] Taha, H.A. 2007. Operations Research An Introduction. Eighth Edition. New Jersey: Pearson Education, Inc.

[6] Gross, D and C.M Harris. 1998. Fundamental of Queueing Theory. Third Edition. New York: John Wiley and Sons, Inc.. 